\title{
Syntaxin-Binding Protein 2
}

National Cancer Institute

\section{Source}

National Cancer Institute. Syntaxin-Binding Protein 2. NCI Thesaurus. Code C114624.

Syntaxin-binding protein 2 (593 aa, $\sim 66 \mathrm{kDa}$ ) is encoded by the human STXBP2 gene.

This protein is involved in intracellular vesicle trafficking and membrane fusion. 